\begin{tabular}{|c|c|c|c|c|c|}
\hline \multicolumn{6}{|c|}{ 富山医科薬科大学医学部第二内科 } \\
\hline 余川 & 茂○ & 杉本 & 恒明 & 浦岡 & 忠夫 \\
\hline 井内 & 和幸 & 秋山 & 真 & 能沢 & \\
\hline
\end{tabular}

\title{
THE SIGNIFICANCE OF EXERCISE TESTS AS PROVOCATIVE OR DIAGNOSTIC INTERVENTIONS FOR ARRHYTHMIAS
}

\author{
Shigeru Yokawa, MD, Tsuneaki Sugrmoto, MD, Tadao URAOKA, MD, \\ Kazuyuki IUCHI, MD, Makoto AKIYAMA, MD \\ and Takashi NozAwA, MD \\ The Second Department of Internal Medicine, Toyama Medical \\ and Pharmaceutical University School of Medicine
}

\begin{abstract}
概要 運動負荷試験が，不整脈の誘発拉よびその病因診断において，どの程度の有用性をもつ かを, treadmill垔最大運動負荷試験を行なつた1148人を対象として調べた，運動負荷により93 人で心室期外収縮，4人で心室頻拍，50人で上室期外収縮，3人で心房細動が誘発された。心 室期外収縮の出現頻度，左室源性の心室期外收縮の出現頻度は負荷試駼陽性群で多かつたか， 心室期外取縮出現時の心拍数には負荷試験陽性群之除性群で差はなからた。，室期外収縮以外 の不整眽の出現頻度と運動負荷試験の結果には，明らかな関保はなかつた。すでに発作の確認 されている頻拍発作症例で，運動に上り，その頻拍発作が再現されたものは，発作性心室頻拍 例 4 人中 2 人, 発作性心房細動例 11 人中 2 人であり, 発作性上室頻拍は誘発されなかつた。負 荷前の洞頻度が每分60未满で，かつ運動中の心拍数が每分120亿達しなからた20例のうち 3 例の 及が，洞不全症候群症例であつた。 また，洞不全症候群症例に招いて，運動中の心拍数が目標 心拍数に達したものと, 達しなかつたものとでは, 長時間心電図上の最大RR間隔, 右房高頻度 刺激後の洞自動能回復時間に差はなかつた，以上より，運動負荷試験は，不整脈の病因診断， 頻拍発作例での不整脈誘発法として限界があり，洞不全症候群の診断法としては有用でないと 思われた。
\end{abstract}

\section{緒 言}

運動負荷試験は，虚血性心疾患の診断，治療効 果の判定に広く用いられているが，近年は不整脈 の診断，誘発法にも用いられつつある。日常臨床 に括いて，運動負荷試験を不整脈の検討に用いる のは，第 1 に，労作時の不整脈が疑われる症例に おいて，これを誘発，再現させる場合，第 2 に，

【昭和58年 2 月 15 日受稿〕

本論文の要旨は第79回日本内科学会講演会（1982年 4 月 3 一 5 日，東京都）括よび第16回国際内科学会議（1982年 8 月22〜27日，ブラ八市）に括いて発表した。
安静時すでに存在する不整脈が，運動によつて， ぞのように変化するかをみる場合，第 3 に，上記 二つの場合における心筋虚血の関与を問題にする 場合などがある，以上の観点から，われわれは運 動負荷試験が，不整脈の誘発技よび，その病因診 断において，亡の程度の有用性をもつるのである かをみるためtreadmill運動負荷時に認められた 不整脈について検討した。

\section{対象と方法}

対象は, 1980年 1 月から 2 年間で, 富山医科薬 科大学附属病院に括いてtreadmill運動負荷心電 
図を記録したもののうち，抗不整脈薬投与をらけ ていない1148人である。その内訳は, 男777人, 女 371 人, 年令は $12 \sim 89$ 才である. 㚘心症誘発を目的 として負荷試験を行なつたもの774人, 不整脈診断 を目的としたもの $205 人$ ，その他の目的で行なつた もの169人である。

運動負荷試験は，treadmillを用い，Bruce変法 （原法の62.5\%のspeed）による多段階運動負荷之 し, Ellestad")の年令別最大心拍数の $85 \%$ を目標心 拍数とした亜最大試験を行なつた，中止点は，目 標心拍数に達したとき，狭心痛が出現したとき， 呼吸困難や下肢の疲労などの自覚症状のため，む はや運動を続けることができなくなつたとき，一 般に危険とされている不整脈の出現したとき， たは，進行性のST低下がみられたときとした。運 動前に坐位执よびtreadmill上立位で $1 \sim 3$ 分間 の連続圧縮心電図記録を行ない，運動中，運動後 は6 channelの心電計で，1分每に20秒間の12誘導 心電図を記録した。一部症例では，12誘導心電図 を記録する間， 6 誘導( I， II， $\mathrm{aVF}, \mathrm{V}_{1}, \mathrm{~V}_{3}, \mathrm{~V}_{5}$ ) の連続圧縮心電図記録を行ない, 運動前, 中, 後 を通じ持続的に心電図を記録した。運動中，後の 各段階で 1 分毎に記録した20秒間の心電図記録に とらえられた心室期外収縮数を数え，その最高の 個数を運動前と比較した。運動中, 後を通じ連続 的に心電図を記録した例では，1 分間毎の心室期 外収縮数を数元，そのうちの最高の個数を，運動 前の連続玨縮心電図にとらえられたものと比較し た，単位時間めたりの心室期外収縮数が，遭動前 に比べて $25 \%$ 以上，增加李たは减少した場合を， 運動による変化とした。

$\mathrm{aVR}$ を除く11誘導のいずれかで，J点か580 $\mathrm{msec}$ の点で $1 \mathrm{~mm}$ 以上の水平または下降型のST 低下，あるいは $\mathrm{J}$ 点から40msecの点で $1 \mathrm{~mm}$ 以上 の水平または上り傾斜型のST上昇を認めた場合 を陽性とした。 1148 人中, 運動負荷試験陽性は254 人, 運動負荷試験陰性は543人であつた.ST変化が 扣こらないうちに，自覚症状のため目標心拍数に 達しないまま試験を中止したものや，心室肥大， 心室内伝導障害, WPW症候群などがあり, 運動負
荷時のST変化を虚血反応と解釈することに問題 のあるもの351人を判定不能とした。

\section{結 果}

\section{1. 運動負荷試験により出現した不整脈}

運動前の連続記録で不整脈を認めず，運動負荷 中または負荷後 5 分以内に，はじめて出現した不 整脈のらち，もつとも頻度の高い不整脈は心室期 外收縮であり93人 (8.1\%) に出現した，運動中に 出現したものは75人（6.5\%)，運動後に出現した あのは18人（1.6\%)であつた。ついで多いのは上 室期外収縮であり 50 人 (4.4\%) に出現した。 上室 期外収縮が運動中に出現したものは46人 (4.0\%)，

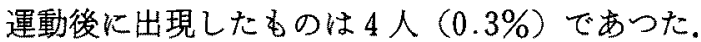
3 個以上の心室期外収縮が連続するものを心室頻 拍とすると，これが誘発されたものは 4 人であつ た。，房細動が誘発されたものは 3 人であつた。 心室頻拍㧍よび心房細動は，いずれる運動中に誘 発された，洞房ブロックは，2 人に扣いて認めら れ，いずれも運動終了 1 分以内に出現した(表 1 ).

運動負荷により出現した不整脈と，負荷試験結 果との関係についてみると，心室期外収縮は，負 荷心電図虚血反応陽性群（以下， $\mathrm{P}$ 群）では37人 $(14.6 \%)$ ，負荷心電図虚血反応陰性群（以下， $\mathrm{N}$ 群) では38人 (7.0\%) 飞出現し，前者において高 頻度であつた。上室期外収縮は $\mathrm{P}$ 群で16人 (6.3\%)，N群で19人（3.5\%）に出現した，心室 頻拍についてはP群のうち 2 人， N群で 1 人に出 現し，心房細動は $\mathrm{P}$ 群で 1 人， N 群で 1 人に認め た。洞房プロック 2 人は，いずれも負荷試験が陰 性之判定されたものであつた（表 2).

\section{2. 運動負荷によク出現した心室性不整脈}

全例について，心室期外収縮の出現と年令との 関係をみると，39才までの 254 人中 12 人 $(4.7 \%)$ ， $40 \sim 50$ 才の 610 人中 40 人 (6.6\%)，60才以上の 284 人中 41 人 $(14.4 \%)$ に心室期外収縮が出現した。 $\mathrm{P}$ 群と N群にわけてみても，60才以上の高令者で 心室期外収縮の出現頻度が高かつた（表 3 ）。

運動負荷により誘発された心室期外収縮を心電 図上の波形により右脚ブロック型の左室源性のも のと, 左脚ブロック型の右室源性のものとに分け 
表 1。運動負荷試験により出現した不整脈の種類別頻度

\begin{tabular}{|c|c|c|c|c|c|}
\hline & 心室期外収縮 & 心室頻拍 & 上室期外収䧽 & 心㰾細動 & 洞房ブロック \\
\hline $\begin{array}{l}\text { 運偊中に誘発 } \\
\text { されたもの }\end{array}$ & $\begin{array}{c}75 \\
(6.5 \%)\end{array}$ & $\begin{array}{c}4 \\
(0.3 \%)\end{array}$ & $\begin{array}{c}46 \\
(4.0 \%)\end{array}$ & $\begin{array}{c}3 \\
(0.3 \%)\end{array}$ & 0 \\
\hline $\begin{array}{l}\text { 運䡃後に誘発 } \\
\text { きれたもの }\end{array}$ & $\begin{array}{c}18 \\
(1.6 \%)\end{array}$ & 0 & $\begin{array}{c}4 \\
(0.3 \%)\end{array}$ & 0 & $\begin{array}{c}2 \\
(0.2 \%)\end{array}$ \\
\hline 計 & $\begin{array}{c}93 \\
(8.1 \%)\end{array}$ & $\begin{array}{c}4 \\
(0.3 \%)\end{array}$ & $\begin{array}{c}50 \\
(4.3 \%)\end{array}$ & $\begin{array}{c}3 \\
(0.3 \%)\end{array}$ & $\begin{array}{c}2 \\
(0.2 \%)\end{array}$ \\
\hline
\end{tabular}

表 2．運動負荷心より出現した不整脈と，負荷試験結果との関係

\begin{tabular}{|c|c|c|c|c|c|}
\hline & 心窒期外收縮 & 心室頻拍 & 上室期外収縮 & 心婘紐動 & 洞庰フロック \\
\hline $\begin{array}{l}\text { 運動角荷試験 } \\
\text { 陽性（254） }\end{array}$ & $\begin{array}{c}37 \\
(14.6 \%)\end{array}$ & $(0.8 \%)$ & $\begin{array}{c}16 \\
(6.3 \%)\end{array}$ & $\left(\begin{array}{c}1 \\
(0.4 \%)\end{array}\right.$ & 0 \\
\hline $\begin{array}{l}\text { 運動負荷試験 } \\
\text { 陻性 } \quad(543)\end{array}$ & $\begin{array}{c}38 \\
(7.0 \%)\end{array}$ & $(0.2 \%)$ & $\begin{array}{c}19 \\
(3.5 \%)\end{array}$ & $(0.2 \%)$ & $(0.4 \%)$ \\
\hline $\begin{array}{l}\text { 運動負荷試験 } \\
\text { 判定不能 (351) }\end{array}$ & $\begin{array}{c}18 \\
(5.1 \%)\end{array}$ & $\left(\begin{array}{c}1 \\
(0.3 \%)\end{array}\right.$ & $\begin{array}{c}15 \\
(4.3 \%)\end{array}$ & $\begin{array}{c}1 \\
(0.3 \%)\end{array}$ & 0 \\
\hline 計（1148） & $\begin{array}{c}93 \\
(8.1 \%)\end{array}$ & $(0.3 \%)$ & $\begin{array}{c}50 \\
(4.4 \%)\end{array}$ & $\left(\begin{array}{c}3 \\
(0.3 \%)\end{array}\right.$ & $(0.2 \%)$ \\
\hline
\end{tabular}

表 3. 年令と心室期外收穛の出現頻度との関䋆

\begin{tabular}{|c|c|c|c|}
\hline & $\leqq 39 才$ & $40-59 才$ & $\geqq 60$ 才 \\
\hline $\begin{array}{l}\text { 連動負荷試験 } \\
\text { 懪性 (254) }\end{array}$ & $0 / 19$ & $\begin{array}{c}16 / 139 \\
(11.5 \%)\end{array}$ & $\begin{array}{c}21 / 96 \\
(21.9 \%)\end{array}$ \\
\hline $\begin{array}{l}\text { 運動負荷試験 } \\
\text { 陰性 (543) }\end{array}$ & $\begin{array}{l}11 / 172 \\
(6.4 \%)\end{array}$ & $\begin{array}{l}16 / 290 \\
(5.5 \%)\end{array}$ & $\begin{array}{c}11 / 81 \\
(13.6 \%)\end{array}$ \\
\hline $\begin{array}{l}\text { 軍動負 荷試験 } \\
\text { 判定不能 (351) }\end{array}$ & $\begin{array}{c}1 / 63 \\
(1.6 \%)\end{array}$ & $\begin{array}{c}8 / 181 \\
(4.4 \%)\end{array}$ & $\begin{array}{c}9 / 107 \\
(8.4 \%)\end{array}$ \\
\hline 計 (1148) & $\begin{array}{l}12 / 254 \\
(4.7 \%)\end{array}$ & $\begin{array}{l}40 / 610 \\
(6.6 \%)\end{array}$ & $\begin{array}{c}41 / 284 \\
(14.4 \%)\end{array}$ \\
\hline
\end{tabular}

てみた，N群では，大半が右室源性であつたが， $\mathrm{P}$ 群では左室源性の心室期外収縮が $45.9 \%$ です り，N群に比べ高率であつた。多源性のものは， P群の 2 人に認められた（図 1 ).

二つ以上の心室期外収縮が連続する連続性心室 性不整脈の頻度は，P群，N群で明らかな差はな かつた。

心室期外収縮が，はじめて出現したときの心拍 数をみると，P群，N群ともに130/分以下で出現 するものが大半であり，両群間で差はなかつた(図 2 ).

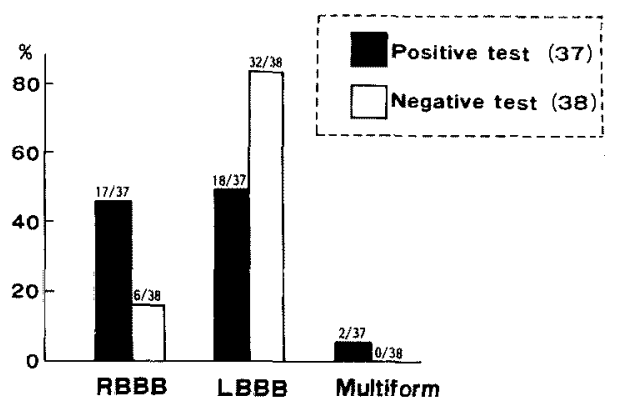

図 1。運動負荷により誘発された心室期外収縮の心電 図上の波形

$\mathrm{RBBB}$ ：右脚ブロック型 (左室源性) D心室期外收縮 LBBB：左脚ブロック型（右室源性）の心室期外収絔 Multiform：多形性（多源性）の心室期外收樎

\section{3. 安静時すでに存在する心室期外収縮に対す る運動の影響}

安静時，すでに心室期外収縮が認められたもの は, P群のらち10人， N群のらち30人であつた。 この安静時に存在した心室期外收縮の運動中，運 動後の変化を図 3 に示す，P群では，運動中に増 加ないし不変のものが $60 \%$ ，運動後に増加または 不変のるの゙50\%であつた。一方，N群では，は 


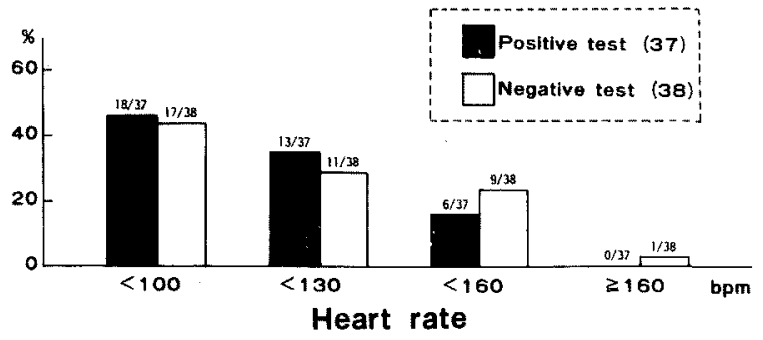

図 2，心室期外収樎が最初に出現したときの心拍数
とんどが運動により減少ないし消失した。亦た， 多源性，2連発に変化したものは，两群にみとめ られた。

\section{4. 運動による頻拍発作の誘発}

すでに発作の確認されている発作性心室頻拍 4 人，発作性上室頻拍 23 人，発作性心房細動 11 人の らち，運動により再現されたものは，扣の沶の， 2 人 $(50 \%), 0 \%, 2$ 人 $(18.2 \%)$ であつた.

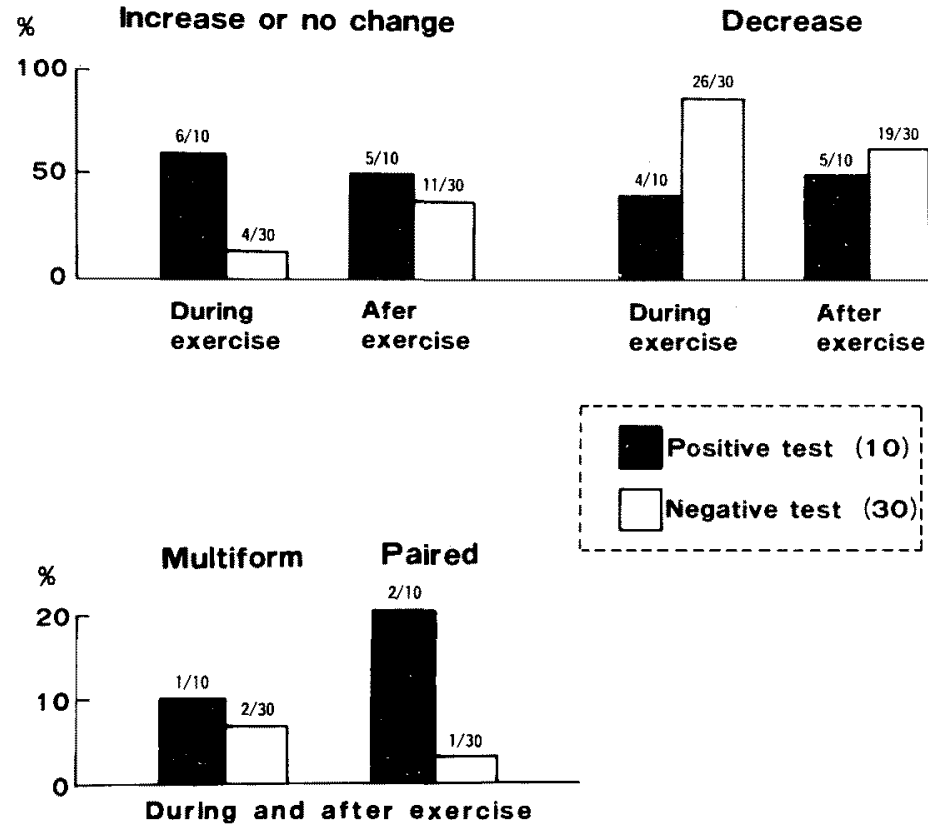

因 3. 安静時に存在する心室期外収縮の運動による变化

表 4. 洞不全症候群症例の臨床所見

\begin{tabular}{|c|c|c|c|c|c|}
\hline & 症洌 & $\begin{array}{l}\text { 年令 } \\
(才)\end{array}$ & 心䉓図所見 & 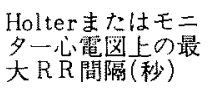 & $\begin{array}{l}\text { 洞自動能回 } \\
\text { 復時間(秒) }\end{array}$ \\
\hline \multirow{5}{*}{$\begin{array}{l}\text { 運動負荷時, } \\
\text { 目標心拍数に } \\
\text { 達したもの }\end{array}$} & KM & 54 & \multirow{5}{*}{ 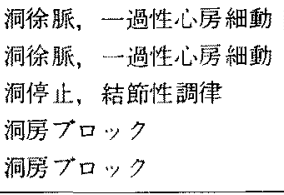 } & 1.52 & 2740 \\
\hline & $\mathrm{NA}$ & 73 & & 1.50 & 4060 \\
\hline & E K & 38 & & 3.12 & 2940 \\
\hline & T K & 68 & & 2.48 & 1700 \\
\hline & S S & 68 & & 1.84 & 3760 \\
\hline \multirow{5}{*}{$\begin{array}{l}\text { 運動負荷時, } \\
\text { 目標心拍数に } \\
\text { 達しなかつた } \\
\text { もの }\end{array}$} & $\mathrm{MO}$ & 76 & \multirow{5}{*}{$\begin{array}{l}\text { 洞停止, 結節性調律 } \\
\text { 洞房ブロック，洞徐脈 } \\
\text { 洞房ブロック，洞徐脈 } \\
\text { 洞徐脈，一過性心房細動 } \\
\text { 洞徐脈 }\end{array}$} & 2.00 & 8000 以上 \\
\hline & $\mathrm{TN}$ & 60 & & 2.32 & 11760 \\
\hline & $\mathrm{SU}$ & 52 & & 2.90 & 3960 \\
\hline & $\mathrm{SN}$ & 53 & & 2.05 & 1400 \\
\hline & KI & 53 & & 1.43 & 1740 \\
\hline
\end{tabular}




\section{5. 洞徐脈例, 洞不全症候群における運動時心拍 数の変化}

洞不全症候群では，運動に対する心拍数の増加 が悪く，最大洞頻度が120/分未満のことが多いと いわれている23). そこで，今回の対象者の中で, 狭心痛を抗こさなかつた症例の5ら，負荷前， treadmill上立位での洞頻度が60/分末満で，かつ 運動中の心拍数が $120 /$ 分に達せずall outとなつた 20人について検討したところ，臨床的に洞不全症 候群と診断されたものは 3 人のみであつた。をた， 今回の対象者のうち，洞不全症候群症例は 10 人で あつたが，目標心拍数に達したものは 5 人，達し なかつたものは 5 人であつた。モニターまたは Holter心電図などの長時間心電図でとらえられ た最大RR間隔および, 右房高頻度刺激後の洞自動 能回復時間を, 目標心拍数に達したものと, 達し なかつたものとで比較したが，明らかな差はなか つた（表 4 ).

\section{考案}

1. 心室性不整脈

運動負荷により各種の不整脈, 伝導障害が誘発 されることが知られている。もつとも頻度の高い ものは心室期外収縮であり，心室頻拍，心室細動 などの致死的不整脈への䔟行の可能性がある点か ら，突然死の問題と関連したものとして注目され

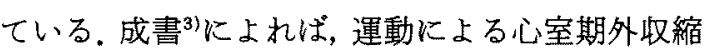
の発生あるいは消失には，(1)交感神経系興奮に上 る異所性自動能え進，(2)心筋虚血によるェント リーの成立, (3)運動時の洞性頻脈が異所性興奮の overdrive suppressionをおこすこと，が関与して いるとされている。この他に，(4)運動時の心拍出 量増加，血王上昇に伴亏心室筋の伸展も重要な因 子であると考えられる。心筋伸展の状態で交感神 経活動が加わると, 心室珄不整脈は一層, 起こり やすくなる4.これらの各因子のかねあいで，運動 による心室期外収縮の発生，あるいは消失が括こ るものと思われる.以上の観点から，今回，運動 負荷時の心室期外収樎の出現様式を, 運動負荷心 電図上の虚血反応と対比検討した。

まず，運動により誘発された心室期外収縮の出
現頻度は，今回の成績では8.1\%であつた。これま

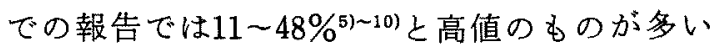
が，刘象者の年令，運動強度，対象者に扣ける心 疾患の比率などによつて心室期外収絔の発生頻度 は異なると思われる。亦た，今回は間久的な心電 因記録にとらえられた心室期外収縮について検討 していることも，出現頻度の少ない原因であろう。 年代別にみると60才以上の高令者で心室期外收縮 の出現頻度が高かつたが，Farisら ${ }^{8)}$ は，年代別で 有意な差はないと報告している。乙かし，村山5), McHenry ら²，高令者ほど心室期外収縮の出現 率が高いと報告して扣り，今回の結果と一致する。 運動負荷時の心室期外収縮出現は, 虚血性心疾患, 心筋炎や心筋症などの心筋障害, 僧帽升逸脱症候 群，QT延長症候群などで高頻度であるといわれ ている ${ }^{11)}$. 今回は, 運動負荷心電図の虚血反応の有 無と心室期外収縮の出現頻度との関係について検 討したが，陽性群の方が陰性群よりも心室期外収 縮の出現頻度が高かつた。これまでの報告でも， 虚血性心疾患を有する例の方が，そうでない例よ りも運動負荷による心室期外収縮の出現頻度が高 いという成績が多い。もちろん，今回の運動負荷 心電図のST変化の中には，心筋虚血によらないも のも含まれている可能性は考えておかなければな らない.

心室期外収縮の心電図上の波形については，例 外はあるが ${ }^{122}$, 左脚ブロック型は右室源性, 右脚プ ロック型は左室源性とされておりり ${ }^{13)}$, 健康人でみ られる心室期外収縮は前者が，心疾患患者では後 者が多(14)といわれている.今回, 運動負荷試験陰 性群で出現した心室期外収縮は大半が右室源性で あつたが，運動負荷試験踼性群で出現した心室期 外収縮は，約半数が左室源性であつた。この結果 からは，左室源性の心室期外収縮が出現すれば, 虚血性心疾患を疑う根拠としてよいと思われる が，右室源性の心室期外収縮であつても虚血性心 疾患は否定できないといえる。

運動負荷により誘発された連続性の心室性不整 脈の頻度には，運動負荷試験陽性群，陰性群で明 らかな差がなかつた。 3 個以上連続する心室期外 
収縮を心室頻拍とすると，今回の検討では 4 人 （0.3\%）の心室頻拍がみとめられた，心室頻拍が 運動負荷により誘発されることはまれである。 Codiniら ${ }^{15)}$ は，連続5730回の運動負荷試験で 8 人 (0.1\%), Ellestadら"は, 4028回の最大運動負荷で 9 人 $(0.2 \%)$ に心室頻拍を認めている。これらの 症例は，ほとんどが自然に洞調律にもどつている。 今回みられた心室頻拍症例の5ち，2人は運動負 荷試験陽性であり，1人は陰性，1人は目標心拍 数に達しないらちに心室頻拍が誘発されたが，心 室頻拍発生直前の心電図にはSTの变化がみられ なからた，結局，虚血が関与していると思われる 心室頻拍は 4 人中 2 人 $(50 \%)$ であつた.

Selzer ${ }^{16)}$ は, 運動負荷試験時の虚血反応を疑 う徵候として，心拍数 $130 /$ 分未満で出現する心室 期外収縮を重視している。しかし，今回，運動負 荷試験陽性群，陰性群之も130/分未満の心拍数で 心室期外収樎の出現するものが大半であり，これ と異なるるのであつた。

運動中の心室期外収縮数について，従来，運動 中に消失する心室期外収樎は正常例に多く，増加 するるのは心疾患に多いといわれている，今回， 運動中に增加するものは，運動負荷試験陽性群に 多かつたが，運動後の増減については，両群で差 はなかつた。運動負荷試験陽性群でも運動中に心 室期外収縮が減少ないし消失したすのが40\%すあ り，心室期外収縮が運動により減少しても，必ず しも正常反応とはいえないまた，多形性，2連 発に変化するるのは両群ともにみられた，その頻 度については，今回は例数が少ないため意味はつ けられず，今後の検討が必要と考えられる。

\section{2.上室性不整脈}

上室期外収縮は，心室期外収縮に比べて運動負 荷により誘発されることが少なく，その発生機序 に関しても不明の点が多い，今回の結果も，運動 負荷試験陽性群，陰性群で上室期外収縮発生頻度 に差がなく，運動による上室期外収樎の出現は， 虚血性心疾患との関連性という点では意義がない よらに思われた，心房細動，上室頻拍などの上室 性の頻拍が出現する頻度は，さらに少ないといわ
れている. Goochら ${ }^{17)}$ は，713人の亜最大負荷試験 で 2 人に心房細動の出現を認めている.今回，上 室頻拍は誘発されなかつたが，心房細動は 3 人で 誘発され，1人は甲状腺機能元進症であつた，村 $山^{5)}$ は，甲状腺機能六進症に伴う一過性の心房細 動が、しばしば運動により誘発されたとしている。 上室性不整脈症例における運動負荷試験は，発作 として訴えられている不整脈を再現させる方法と しての価值はあるという程度のものと思われる.

\section{3. 洞不全症候群}

洞不全症候群では，運動時の心拍数増加が少な い(18)19)といわれている.Holdenら ${ }^{18)}$ は，洞不全症 候群症例之，年令を対応させた正常者に最大運動 負荷を行ない，最大酸素摂取量には差がなかつた が，洞不全症候群症例では最大心拍数が有意に低 かつたと報告している. Chung ${ }^{3 /}$ は，洞不全症候群 症例では，通常の運動負荷のprotocolでは心拍数 が120/分に達することは少ないと述べている．今 回，洞不全症候群症例と，そうでない洞徐脈例の 鑑別に運動負荷試験が有用であるかどうかをみる 目的で，安静時に洞徐脈があり，運動中の心拍数 が120/分に達しないらちにall outとなつた症例20 人について検討したが，臨床的に洞不全症候群と 診断されたものは 3 人のみであつた。今回の対象 者のらち, 洞不全症候群症例は 10 人であつたが, 目標心拍数（年令別最大予測心拍数の $85 \%$ ）に達 したるのは 5 人，達しなかつたものは 5 人と差が なく，またモ二タ一上の最大RR間隔，洞自動能 回復時間む，目標心拍数に達したものと，達しな かつたものとで差がなかつた，今回は例数は少な いが，この結果からは，運動時の心拍数の増方方 をみることは，洞不全症候群の診断招よび病態の 理解には，あまり有用でないとい党々うである。

\section{まとめ}

1）運動負荷試験陽性群では，心室期外収縮の出 現頻度が，陰性群の7.0\%に対して $14.6 \%$ と高く， 左室源性の心室期外収縮が多かつた。しかし，心 室期外収縮出現時の心拍数には運動負荷試験陽性 群と陰性群とでは差がなかつた。

2）心室期外収縮以外の不整脈の出現頻度には, 
運動負荷試験陽性群と陰性群とでは，明らかな差 がなかつた。

3）すでに発作の確認されている頻拍発作例で， 運動により頻拍が誘発されたものは，発作性心室 頻拍 $50 \%$ ，発作性心房細動18.2\%ですり，発作性 上室頻拍は誘発されなかつた。

4) 洞不全症候群症例に打いて, 運動中の心拍数 が目標心拍数に達しえたものと，達しなかつたす のとで, 臨休像に差はなかつた。

5）以上より，運動負荷試験は，不整脈の病因診 断扣よび頻拍発作例での不整脈誘発法として限界 があり，また，洞不全症候群の診断法としては有 用でないと思われた。

\section{文献}

1) Ellestad $\mathrm{MH}_{\text {, et al : Maximal treadmill stress }}$ testing for cardiovascular evaluation. Circulation 39: 517, 1969.

2) Le Heuzey JY, et al: Apport de l'épreuve d' effort au diagnostic des dysfonctionnements sinusaux. Arch Mal Cœur $74: 297,1981$.

3) Chung EK: Exercise Electrocardiography. Practical approach. Williams \& Wilkins, Baltimore, 1979, p220.

4) 上田英雄，杉本恒明：中枢性不整脈。臨床科学 4: $1189,1968$.

5）村山正博：実地臨床における不整脈䛦断へのアプ 口-チ。運動負荷試驗。治療 63：1035，1981.

6) Udall JA and Ellestad MH: Predictive implications of ventricular premature contractions associated wih treadmill stress testing. Circulation $56: 985,1977$.

7) McHenry PL, et al: Cardiac arrhythmias observed during maximal treadmill exercise testing in clinically normal men. Amer J Cardiol $29: 331,1972$.

8) Faris JV, et al: Prevalence and reproducibility of exercise-induced ventricular arrhythmias during maximal exercise testing in normal men. Amer J Cardiol $37: 617,1976$.
9) Poblete PF, et al: Detection of ventricular ectopy in patients with cornonary heart disease and normal subjects by exercise testing and ambulatory electrocardiography. Chest $74: 402$, 1978.

10) Froelicher VF, et al : Epidemiologic study of asymptomatic men screened by maximal treadmill testing for latent coronary artery disease. Amer J Cardiol 34 : 770, 1974.

11) Cohn $K$ and Goldschlager $N$ : The significance of arrhythmias in exercise testing. In Cardiac Arrhythmias. (Ed. Mandel WJ) Lippincott, Philadelphia \& Toronto 1980, p396.

12) Josephson ME, et al: Recurrent sustained ventricular tachycardia : Endocardial mapping. Circulation 57: 440, 1978.

13) Rosenbaum MB : Classification of ventricular extrasystoles according to form. J Electrocardiol 2: 289, 1969.

14) Lewis $S$, et al : Significance of site of origin of premature ventricular contractions. Amer Heart J $97: 159,1979$.

15) Codini, MA, et al: Efficacy of coronary bypass grafting in exercise-induced ventricular tachycardia. J Thorac Cardiovasc Surg 81 : 502, 1981.

16) Selzer A, et al: On the interpretation of the exercise test. Circulation 58: 193, 1978.

17) Gooch AS and McConnell D: Analysis of transient arrhythmias and conduction distrubances occuring during submaximall treadmill exercise testing. Prog Cardiovasc Dis 13 : 293, 1970.

18) Holden $W$, et al: Characterisation of heart rate response to exercise in the sick sinus syndrome. Brit Heart J $40: 923,1978$.

19) Vallin $H O$ and Edhag $\mathrm{KO}$ : Heart rate responses in patients with sinus node disease compared to controls: physiological implications and diagnostic possibilities. Clin Cardiol $3: 391,1980$. 